\title{
Erratum to: The prevalence and clinical characteristics of nonradiographic axial spondyloarthritis among patients with inflammatory back pain in rheumatology practices: a multinational, multicenter study
}

Ruben Burgos-Vargas', James Cheng-Chung Wei ${ }^{2,3,4^{*}}$, Mahboob U. Rahman ${ }^{5,6}$, Nurullah Akkoc ${ }^{7}$, Syed Atiqul Haq ${ }^{8}$, Mohammed Hammoudeh ${ }^{9}$, Ehab Mahgoub ${ }^{6}$, Ena Singh ${ }^{6}$, Lyndon John Llamado ${ }^{10}$, Khalid Shirazy ${ }^{11}$, Sameer Kotak ${ }^{12}$, Constance Hammond ${ }^{6}$, Ron Pedersen ${ }^{6}$, Qi Shen ${ }^{6}$ and Bonnie Vlahos ${ }^{6}$

Unfortunately, after publication of this article [1], it was noticed that the name of the first author was incorrect. The corrected author list can be seen above and the original article has been updated to reflect this.

\footnotetext{
Author details

'Department of Rheumatology, General Hospital of Mexico, Mexico City, Mexico. ${ }^{2}$ Division of Allergy, Immunology and Rheumatology, Chung Shan Medical University Hospital, No. 110, Sec. 1, Jianguo N. Road, Taichung City 40201, South District, Taiwan. ${ }^{3}$ Institute of Medicine, Chung Shan Medical University, Taichung City, Taiwan. ${ }^{4}$ Graduate Institute of Integrated Medicine, China Medical University, Taichung City, Taiwan. ${ }^{5}$ University of Pennsylvania, Philadelphia, PA, USA. ${ }^{6}$ Pfizer, Collegeville, PA, USA. 'Dokuz Eylül University, Izmir, Turkey. ${ }^{8}$ Bangabandhu Sheikh Mujib Medical University, Dhaka, Bangladesh. ${ }^{9}$ Hamad Hospital, Doha, Qatar. ${ }^{10}$ Pfizer Asia Pacific Region, Makati, Philippines. ${ }^{11}$ Pfizer Africa and Middle East Region, Dubai, United Arab Emirates. ${ }^{12}$ Pfizer, New York, NY, USA.
}

Received: 28 June 2016 Accepted: 28 June 2016

Published online: 04 July 2016

\section{Reference}

1. Burgos-Vargas R, Wei JC-C, Rahman MU, Akkoc N, Haq SA, Mohammed H, Mahgoub E, Singh E, Llamado LJ, Shirazy K, Kotak S, Hammond C, Pedersen R, Qi S, Vlahos B. The prevalence and clinical characteristics of nonradiographic axial spondyloarthritis among patients with inflammatory back pain in rheumatology practices: a multinational, multicenter study. Arthr Res Ther. 2016;18:132. doi:10.1186/s13075-016$1027-9$

\footnotetext{
* Correspondence: jccwei@gmail.com

2Division of Allergy, Immunology and Rheumatology, Chung Shan Medical University Hospital, No. 110, Sec. 1, Jianguo N. Road, Taichung City 40201, South District, Taiwan

${ }^{3}$ Institute of Medicine, Chung Shan Medical University, Taichung City, Taiwan Full list of author information is available at the end of the article
}

\footnotetext{
Submit your next manuscript to BioMed Central and we will help you at every step:

- We accept pre-submission inquiries

- Our selector tool helps you to find the most relevant journal

- We provide round the clock customer support

- Convenient online submission

- Thorough peer review

- Inclusion in PubMed and all major indexing services

- Maximum visibility for your research
}

Submit your manuscript at www.biomedcentral.com/submit (c) 2016 The Author(s). Open Access This article is distributed under the terms of the Creative Commons Attribution 4.0 International License (http://creativecommons.org/licenses/by/4.0/), which permits unrestricted use, distribution, and reproduction in any medium, provided you give appropriate credit to the original author(s) and the source, provide a link to the Creative Commons license, and indicate if changes were made. The Creative Commons Public Domain Dedication waiver (http://creativecommons.org/publicdomain/zero/1.0/) applies to the data made available in this article, unless otherwise stated. 